\title{
PENGEMBANGAN MEDIA PEMBELAJARAN MATA PELAJARAN MATEMATIKA BERBASIS PENDIDIKAN KARAKTER DI SEKOLAH MENENGAH ATAS NEGERI 1 BOYOLANGU
}

\author{
Samsul Bakri \\ Jurusan Tadris Matematika Fakultas Tarbiyah dan Ilmu Keguruan \\ Institut Agama Islam Negeri (IAIN) Tulungagung
}

\begin{abstract}
Abstrak
Artikel ini merupakan penelitian pengembangan media berbasis pendidikan karakter yang menggunakan kaidah-kaidah pengembangan produk dari Borg \& Gall, yang meliputi: pendahuluan, pengembangan, uji lapangan dan diseminasi. Dengan menggunakan langkah-langkah penelitian dan pengembangan, model pengembangan program pembelajaran, dan langkah-langkah pengembangan media, dapat dihasilkan media pembelajaran berbasis pendidikan karakter untuk mata pelajaran matematika yang efektif. Kualitas media pembelajaran berbasis pendidikan karakter hasil pengembangan ini, dari berbagai aspek dapat dinyatakan baik. Penggunaan media berbasis pendidikan karakter ini dapat berdampak baik terhadap hasil pembelajaran, dan aspek afektif pebelajar.
\end{abstract}

Kata Kunci: Media Pembelajaran, Pendidikan Karakter

\section{PENDAHULUAN}

Tantangan utama bangsa Indonesia dewasa ini dan di masa depan adalah kemampuan untuk meningkatkan kualitas sumber daya manusia. Dalam kaitan ini menarik untuk dikaji kualitas pendidikan dan upaya yang dapat dilakukan untuk meningkatkan kualitas pendidikan sehingga bisa menghasilkan sumber daya manusia yang lebih berkualitas sebagaimana diharapkan, agar bangsa Indonesia menjadi bangsa yang produktif, efisien, dan memiliki kepercayaan diri yang kuat sehingga mampu bersaing dengan bangsa-bangsa lain dalam kehidupan global ini.

Pembelajaran dewasa ini menghadapi dua tantangan, tantangan yang pertama datang dari adanya perubahan persepsi tentang belajar itu sendiri dan tantangan yang kedua datang dari adanya teknologi informasi dan telekomunikasi yang memperlihatkan perkembangan yang luar biasa. Konstruktivisme pada dasarnya telah menjawab tantangan yang pertama dengan meredefinisi belajar sebagai proses konstruktif di mana informasi diubah menjadi pengetahuan melalui proses interpretasi, korespondensi, representasi, dan elaborasi. Sementara itu, kemajuan teknologi informasi dan telekomunikasi yang begitu pesat yang menawarkan berbagai kemudahan-kemudahan baru dalam pembelajaran memungkinkan terjadinya pergeseran orientasi belajar dari outside-guided menjadi selfguided dan dari knowledge-as-possession menjadi knowledge-as-construction. Lebih dari itu, 
teknologi ini ternyata turut pula memainkan peran penting dalam memperbarui konsepsi pembenaran yang semula fokus pada pembelajaran sebagai semata-mata suatu penyajian berbagai pengetahuan menjadi pembelajaran sebagai suatu bimbingan agar mampu melakukan eksplorasi sosial-budaya yang kaya akan pengetahuan.

Dalam bidang pendidikan dan pelatihan, proses pembelajaran diidentikkan dengan proses penyampaian informasi atau komunikasi. Dalam hal ini media pembelajaran merupakan bagian yang tak terpisahkan pada lembaga pendidikan. Pemanfaatan media pembelajaran merupakan upaya kreatif dan sistematis untuk menciptakan pengalaman yang dapat membelajarkan pebelajar, sehingga pada akhirnya lembaga pendidikan akan mampu menghasilkan lulusan yang berkualitas.

Selama ini ada dua permasalahan yang berkenaan dengan penggunaan media pembelajaran di SMAN 1 Boyolangu. Selama ini ada dua permasalahan yang berkenaan dengan penggunaan media pembelajaran di SMAN 1 Boyolangu, yakni ketersediaan dan pemanfaatan. Ketersediaan media, masih sangat kurang sehingga para pengajar menggunakan media secara minimal. Media yang sering digunakan adalah media cetak (diktat, modul, hand out, buku teks, majalah, surat kabar, dan sebagainya), sementara itu media sederhana yang masih tetap digunakan adalah papan tulis/white board dan kapur/spidol. Sedangkan media audio visual (overhead transparency, video/film, kaset audio, siaran TV/Radio), dan media elektronik (komputer, internet) masih belum secara intensif dimanfaatkan. Masalah kedua, pemanfaatan media. Media cetak merupakan media yang paling sering digunakan oleh pengajar, karena mudah untuk dikembangkan maupun dicari dari berbagai sumber. Namun, kebanyakan media cetak sangat tergantung pada verbal symbols (kata-kata) yang bersifat sangat abstrak, sehingga menuntut kemampuan abstraksi yang sangat tinggi dari pebelajar, hal inilah yang dapat menyulitkan mereka. Karena itu dalam pemanfaatan media ini, diperlukan kreativitas pengajar juga pertimbangan instruksional yang matang dari pengajar. Kenyataan yang sering terlihat adalah, banyak pengajar menggunakan media pembelajaran "seadanya" tanpa pertimbangan pembelajaran (instructional consideration), dan ada pula pengajar yang menggunakan media canggih walaupun sesungguhnya tidak diperlukan dalam pembelajaran, yakni ketersediaan dan pemanfaatan. Ketersediaan media, masih sangat kurang sehingga para pengajar menggunakan media secara minimal. Media yang sering digunakan adalah media cetak (diktat, modul, hand out, buku teks, majalah, surat kabar, dan sebagainya), sementara itu media sederhana yang masih tetap digunakan adalah papan tulis/white board dan kapur/spidol. Sedangkan media audio visual (overhead transparency, video/film, kaset audio, siaran TV/Radio), dan media elektronik (komputer, internet) masih belum secara intensif dimanfaatkan. Masalah kedua, pemanfaatan media. Media cetak merupakan media yang paling sering digunakan oleh pengajar, karena mudah untuk dikembangkan maupun dicari dari berbagai sumber. Namun, kebanyakan media cetak sangat tergantung pada verbal symbols (kata-kata) yang bersifat sangat abstrak, sehingga menuntut kemampuan abstraksi yang sangat tinggi dari pebelajar, hal inilah yang dapat menyulitkan mereka. Karena itu dalam pemanfaatan media ini, diperlukan kreativitas pengajar juga pertimbangan instruksional yang matang dari pengajar. Kenyataan yang sering terlihat adalah, banyak pengajar menggunakan media pembelajaran "seadanya" tanpa pertimbangan pembelajaran (instructional consideration), dan ada pula pengajar yang menggunakan media canggih walaupun sesungguhnya tidak diperlukan dalam pembelajaran.

Banyaknya waktu belajar di kelas, menuntut ruang belajar yang nyaman baik secara fisik maupun secara psikologi. Namun, kenyataan menunjukkan masih ada ruang sempit dengan jumlah 
pebelajar yang cukup banyak, fasilitas seadanya serta kebersihan yang kurang terawat, sehingga bau yang kurang sedap sering singgah. Ada juga suasana kelas yang monoton sehingga tidak menimbulkan gairah belajar. Kekurangan waktu yang sudah diprogramkan dalam Rencana Pelaksanaan Pembelajaran untuk menyampaikan satu materi merupakan keluhan yang sering kali disampaikan oleh pengajar atau pebelajar. Tidak jarang pokok bahasan terakhir atau materi yang dianggap mudah disampaikan hanya sekilas, sehingga sebagai pebelajar tidak mampu menguasai dengan baik.

Di samping itu, permasalahan media yang mampu membimbing pebelajar supaya mempunyai karakter yang baik, atau dapat dikatakan karakter positif juga sangat diperlukan. Hal ini dilakukan supaya pebelajar tidak hanya menjadi orang yang pandai saja, namun juga mempunyai karakter dan mampu mengimplementasikannya dalam kehidupan sehari-hari. Maka dari itu, peneliti melakukan penelitian tentang "Pengembangan Media Pembelajaran Mata Pelajaran Matematika Berbasis Pendidikan Karakter di Sekolah Menengah Atas Negeri 1 Boyolangu". Adapun permasalahan yang peneliti kemukakan adalah: 1) Nilai-nilai apa saja yang diinternalisasikan dalam melalui media pembelajaran mata pelajaran matematika di SMAN 1 Boyolangu? 2) Bagaimana mengembangkan media pembelajaran berbasis pendidikan karakter pada mata pelajaran Matematika di SMAN 1 Boyolangu?

\section{METODE}

Penelitian ini termasuk jenis penelitian dan pengembangan atau dikenal dengan Research and Development (R\&D) atau penelitian dan pengembangan. Penelitian dan pengembangan (R\&D) merupakan jenis penelitian yang beorientasi pada produk. Melalui penelitian dan pengembangan diharapkan dapat menjembatani kesenjangan penelitian yang lebih banyak menguji teori ke arah menghasilkan produk-produk yang dapat digunakan langsung oleh banyak pengguna.

Borg dan Gall (1983: 772) mengartikan pendekatan penelitian dan pengembangan dalam bidang pendidikan dan pembelajaran sebagai "a process used to develop and validate educational products". Menurut Gay (1990) pendekatan penelitian dan pengembangan merupakan suatu usaha untuk mengembangkan produk pendidikan yang efektif yang berupa material pembelajaran, media, strategi, atau material lainnya dalam pembelajaran untuk digunakan di sekolah, bukan untuk menguji teori. Berdasarkan kedua pendapat tersebut dapat dikatakan bahwa penelitian dan pengembangan dalam bidang pendidikan dan pembelajaran merupakan pendekatan penelitian yang bertujuan untuk mengembangkan dan memvalidasi produk pendidikan dan pembelajaran untuk meningkatkan dan mengembangkan mutu pendidikan dan pembelajaran secara efisien dan adaptabel. Produk dari pendekatan penelitian ini diharapkan dapat dipakai untuk meningkatkan dan mengembangkan mutu pendidikan dan pembelajaran (Anik Ghufron, 2007).

Model pengembangan yang dilakukan dalam penelitian ini adalah model diskriptif prosedural di mana dalam pengembangan produk media pembelajaran menggariskan langkah-langkah yang harus diikuti untuk menghasilkan sebuah produk. Ada tiga tahapan dasar yang harus dilakukan oleh pengembang yaitu konseptualisasi masalah, pembuatan produk, dan uji coba produk. Jika keputusan dapat diterima maka pembuatan produk dapat dimulai dan apabila belum dapat diterima maka proses 


\section{Samsul Bakri}

harus diulangi. Model prosedural inilah yang paling tepat untuk diterapkan dalam penelitian pengembangan produk media pembelajaran berbasis pendidikan karakter.

Selain model di atas, pengembang juga memilih menggunakan software pembelajaran (CD multimedia Interaktif) ini dengan pertimbangan, antara lain (1) software pembelajaran (CD multimedia Interaktif) dapat menggambarkan proses secara tepat dan dapat disaksikan berulangulang, (2) dapat mendorong meningkatkan motivasi belajar, (3) dapat ditunjukkan kepada kelompok besar atau kelompok kecil, (4) dapat menarik perhatian pebelajar, (5) demonstrasi yang sulit dapat dipersiapkan dan direkam sebelumnya sehingga waktu penyajian, guru tinggal memusatkan perhatian pada penyajiannya, dan (6) efisiensi waktu, serta dapat disaksikan berulang-ulang.

Sebagai landasannya, model yang dipakai ini adalah Model Borg \& Gall (1983: 775), dengan beberapa pertimbangan:

1. Model ini memiliki landasan teori preskriptif yang jelas karena teori ini menetapkan metode pembelajaran yang optimal. Hal ini sesuai dengan tujuan kegiatan pengembangan media pembelajaran ini.

2. Langkah-langkah pengembangan model ini terperinci namun sederhana dan tidak kaku.

3. Model ini sebagai cara pemecahan masalah pembelajaran secara operasional.

Model pengembangan yang digunakan dalam tesis ini diadaptasi dari model model pengembangan yang dikemukakan oleh Borg and Gall. Menurut Borg dan Gall (1983) pendekatan penelitian ini memiliki sepuluh langkah pelaksanaan penelitian, yaitu: (1) studi pendahuluan dan pengumpulan data (kaji kepustakaan, pengamatan kelas, membuat kerangka kerja penelitian), (2) perencanaan (merumuskan tujuan penelitian, memperkirakan dana dan waktu yang diperlukan, prosedur kerja penelitian, dan berbagai bentuk partisipasi kegiatan selama kegiatan penelitian), (3) mengembangkan produk awal (perancangan draf awal produk), (4) ujicoba awal (mencobakan draf produk ke wilayah dan subjek yang terbatas), (5) revisi untuk menyusun produk utama (revisi produk berdasarkan hasil uji coba awal), (6) ujicoba lapangan utama (ujicoba terhadap produk hasil revisi ke wilayah dan subjek yang lebih luas), (7) revisi untuk menyusun produk operasional, (8) uji coba produk operasional (uji efektivitas produk), (9) revisi produk final (revisi produk yang efektif dan adaptabel), dan (10) diseminasi dan implementasi produk hasil pengembangan penelitian yaitu perencanaan, pengembangan, uji lapangan dan diseminasi.

Untuk menghasilkan produk pengembangan yang berkualitas diperlukan pula instrumen yang berkualitas dan mampu menggali apa dikehendaki dalam pengembangan produk PBK. Sebagai sebuah produk media yang memerlukan waktu dan biaya yang tinggi, peneliti menggali data dengan instrumen yang sering digunakan oleh ahli lain atau terdapat dalam literatur-literatur yang ada serta divalidasi oleh ahli-ahli materi atau ahli media.

Pengembangan instrumen pengumpul data dilakukan melalui dua tahapan, yaitu penyusunan instrumen dan uji coba instrumen.

\section{a. Penyusunan Instrumen}

Pada tahap ini instrumen penelitian baik kuesioner maupun tes disusun oleh peneliti. Kuesioner disusun berdasarkan kisi-kisi yang telah dikembangkan yang sebagian besar 
diadaptasi dari instrumen penelitian-penelitian pengembangan media yang pernah dilakukan oleh peneliti sebelumnya, dengan modifikasi seperlunya.

b. Uji Coba Instrumen

Pada tahap ini, instrumen yang telah disusun diuji cobakan dengan tujuan memperoleh masukan untuk memperbaiki instrumen sehingga instrumen dapat digunakan sebagai alat ukur yang valid dalam penelitian. Dalam penelitian ini kriteria untuk menentukan kualitas instrumen adalah validitas, khususnya validitas logis. Di samping itu, uji coba ini juga dimaksudkan untuk mengetahui apakah responden memahami item-item dalam instrumen yang telah dikembangkan dan apakah responden dapat membuat pilihan terhadap alternatif jawaban pada setiap item.

Untuk memastikan bahwa instrumen evaluasi untuk ahli media dan ahli materi memiliki validitas logis maka sebelum kuesioner tersebut digunakan untuk mengumpulkan data, terlebih dahulu dikonsultasikan kepada ahli media dan ahli materi untuk mendapatkan penilaian, kritik dan saran perbaikan. Sedangkan instrumen evaluasi untuk pebelajar diujicobakan kepada beberapa pebelajar. Kritik dan saran dari responden uji coba digunakan untuk merevisi instrumen.

Adapun metode dan instrumen pengumpul data dilakukan sebagai berikut: (1) untuk menggali data mengenai kebenaran konsep, peneliti melakukan diskusi dan menyerahkan produk yang dibuat dan lembar evaluasi agar direviu ahli serta mereka diminta memberikan komentar mengenai produk yang akan dihasilkan; (2) untuk menggali kedalaman materi dengan indikator kualitas tampilan dan kualitas pengajaran, digunakan angket dengan menggunakan skala Likert, dan mendiskusikan dengan responden kelompok kecil dan observasi untuk uji coba lapangan; (3) untuk menggali data mengenai efektivitas dan efisiensi produk dilakukan dengan melihat untuk kerja pebelajar dan waktu yang digunakan pada uji coba lapangan; (4) untuk melihat aspek daya tarik dilakukan dengan pengamatan langsung terhadap pebelajar dan dari hasil observasi; (5) peningkatan prestasi belajar pebelajar dilihat dari hasil test dengan hasil test sebelumnya.

Data mengenai tanggapan pebelajar dikumpulkan melalui kuesioner dan dianalisis dengan statistik deskriptif dengan teknik persentase dan kategorisasi. Data-data dan saran-saran yang diperoleh tersebut, dianalisis dan disimpulkan untuk perbaikan produk media berbasis pendidikan karakter yang sudah dibuat. Untuk mengetahui jumlah persentase pebelajar yang mencapai ketuntasan belajar dengan melihat perbedaan nilai pebelajar pada pre-test dan post-test, data yang diperoleh diolah dengan bantuan program excel dan SPSS versi 12.

Teknik yang digunakan untuk memberikan kriteria nilai kualitas produk yang dibuat, yaitu:

1. Data yang diperoleh dari kuesioner tentang tanggapan pebelajar diubah dulu menjadi data interval sebagai berikut:

$\begin{array}{lll}\text { Sangat Baik } & =5(100 \% \text { sesuai dengan unsur-unsur yang ada dalam pertanyaan itu }) \\ \text { Baik } & =4(80 \% \text { sesuai dengan unsur-unsur yang ada dalam pertanyaan itu }) \\ \text { Cukup Baik } & =3(60 \% \text { sesuai dengan unsur-unsur yang ada dalam pertanyaan itu }) \\ \text { Kurang Baik } & =2(40 \% \text { sesuai dengan unsur-unsur yang ada dalam pertanyaan itu }) \\ \text { Sangat Kurang Baik } & =1(20 \% \text { sesuai dengan unsur-unsur yang ada dalam pertanyaan itu })\end{array}$

Dalam kuesioner diberikan lima pilihan untuk memberikan tanggapan tentang produk media berbasis pendidikan karakter yang dikembangkan, yaitu: sangat baik (5), baik (4), cukup baik (3), 
kurang baik (2), dan sangat kurang baik (1). Seandainya pebelajar memberi tanggapan "sangat baik" pada suatu butir pertanyaan, maka skor butir pertanyaan tersebut sebesar " 5 ", demikian seterusnya.

2. Kemudian skor yang diperoleh, dikonversikan menjadi nilai, pada skala 5, dengan acuan tabel sebagai berikut (Sukardjo, 2005):

Tabel 1. Konversi Skor ke Nilai pada Skala 5

\begin{tabular}{ccc}
\hline Interval Skor & Nilai & Kategori \\
\hline $\mathbf{X}>\bar{X}_{i}+1,80 \mathrm{SBi}$ & A & Sangat Baik \\
\hline $\bar{X}_{\mathrm{i}}+0,60 \mathrm{SBi}<\mathbf{X} \leq \bar{X}_{\mathrm{i}}+1,80 \mathrm{SBi}$ & $\mathrm{B}$ & Baik \\
\hline $\bar{X}_{\mathrm{i}}-0,60 \mathrm{SBi}<\mathbf{X} \leq \bar{X}_{\mathrm{i}}+0,60 \mathrm{SBi}$ & $\mathrm{C}$ & Cukup Baik \\
\hline $\bar{X}_{\mathrm{i}}-1,80 \mathrm{SBi}<\mathbf{X} \leq \bar{X}_{\mathrm{i}}-0,60 \mathrm{SBi}$ & $\mathrm{D}$ & Kurang Baik \\
\hline $\mathbf{X} \leq \bar{X}_{\mathrm{i}}-1,80 \mathrm{SBi}$ & $\mathrm{E}$ & Sangat Kurang Baik \\
\hline
\end{tabular}

\section{Keterangan :}

$\bar{X}_{\mathrm{i}}=$ Rerata ideal $\quad=1 / 2($ skor maksimal ideal + skor minimal ideal $)$

$\mathrm{SBi}=$ Simpangan baku ideal $=1 / 6$ (skor maksimal ideal - skor minimal ideal $)$

$\mathrm{X}=$ Skor aktual

Berdasarkan rumus konversi pada tabel 1 di atas, dapat diperoleh gambaran yang jelas dalam mengubah data kuantitatif menjadi data kualitatif. Pedoman pengubahan data kuantitatif menjadi data kualitatif, dipaparkan dalam tabel 2 di bawah ini:

Tabel 2. Pedoman Pengubahan Data Kuantitatif Menjadi Data Kualitatif

\begin{tabular}{ccc}
\hline Interval Skor & Nilai & Kategori \\
\hline $\mathbf{X}>4,21$ & $\mathrm{~A}$ & Sangat Baik \\
\hline $3,40<\mathbf{X} \leq 4,21$ & $\mathrm{~B}$ & Baik \\
\hline $2,60<\mathbf{X} \leq 3,40$ & $\mathrm{C}$ & Cukup Baik \\
\hline $1,79<\mathbf{X} \leq 2,60$ & $\mathrm{D}$ & Kurang Baik \\
\hline $\mathbf{X} \leq 1,79$ & $\mathrm{E}$ & Sangat Kurang Baik
\end{tabular}

\section{Keterangan :}

Skor maksimal $=5$

$$
\begin{aligned}
\bar{X}_{\mathrm{i}} & =1 / 2(5+1)=3 \\
\mathrm{SBi} & =1 / 6(5-1)=0,67
\end{aligned}
$$

Skor minimal $=1$

$\mathrm{X}=$ Skor aktual

c. Untuk mencari skor rata-rata dalam memberikan penilaian produk yang dikembangkan, digunakan rumus:

$$
\bar{X}=\frac{\sum X}{n}
$$

\section{Keterangan:}

$\bar{X} \quad=$ Skor rata-rata

$\sum X=$ Jumlah skor

$n \quad=$ Jumlah responden 
Dengan berpedoman kepada tabel 2 di atas, skor tiap butir tanggapan yang diperoleh, dapat dikonversikan menjadi nilai untuk mengetahui kategori setiap butir tanggapan atau rata-rata secara keseluruhan terhadap media berbasis pendidikan karakter hasil pengembangan. Dengan berpedoman pada tabel tersebut juga akan lebih mudah untuk memberikan suatu kriteria nilai bahwa software media pembelajaran berbasis pendidikan karakter, sudah baik atau belum baik dari aspek pembelajaran, aspek materi, maupun aspek media. Dalam penelitian ini, peneliti memberi nilai kelayakan produk minimal "C", dengan kategori "Cukup Baik", sehingga hasil penilaian, baik dari ahli materi, ahli pendidikan karakter, ahli media maupun pebelajar, jika sudah memberikan hasil penilaian akhir (keseluruhan) dengan nilai minimal "C" (Cukup Baik), produk media berbasis pendidikan karakter hasil pengembangan tersebut sudah dianggap layak digunakan.

Berdasarkan rumus konversi pada tabel 2 di atas, dapat diperoleh gambaran yang jelas dalam mengubah data persentase ketuntasan belajar menjadi data kualitatif. Pedoman pengubahan data persentase ketuntasan belajar menjadi data kualitatif, dipaparkan dalam tabel 3 di bawah ini:

Tabel 3 Pedoman Pengubahan Data Persentase Ketuntasan Belajar Menjadi Data Kualitatif

\begin{tabular}{ccc}
\hline $\begin{array}{c}\text { Interval Persentase } \\
\text { Ketuntasan Belajar }\end{array}$ & Nilai & Kategori \\
\hline $\mathbf{X}>80,2$ & A & Sangat Baik \\
\hline $60,4<\mathbf{X} \leq 80,2$ & B & Baik \\
\hline $40,6<\mathbf{X} \leq 60,4$ & C & Cukup Baik \\
\hline $20,8<\mathbf{X} \leq 40,6$ & D & Kurang Baik \\
\hline $\mathbf{X} \leq 20,8$ & E & Sangat Kurang Baik \\
\hline
\end{tabular}

\section{Keterangan :}

Persentase maksimal $=100$

Persentase minimal $=1$

$\mathrm{X} \quad=$ Persentase aktual

$$
\begin{aligned}
\bar{X}_{\mathrm{i}}= & 1 / 2(100+1)=50,5 \\
& \operatorname{SBi}=1 / 6(100-1)=16,5
\end{aligned}
$$

Dengan berpedoman pada tabel 3 di atas, akan lebih mudah untuk memberikan suatu kriteria nilai bahwa jumlah persentase pebelajar yang mencapai ketuntasan belajar, termasuk dalam kategori: sangat kurang baik, kurang baik, cukup baik, baik atau sangat baik. Untuk mengetahui tingkat ketuntasan belajar pebelajar, peneliti menggunakan nilai minimal " 70 " (rata-rata nilai yang digunakan untuk ketuntasan belajar), sehingga kalau nilai pebelajar pada post-test mendapat nilai minimal 70, pebelajar tersebut dinyatakan sudah mencapai ketuntasan belajar pada materi tersebut.

\section{PEMBAHASAN}

Sebelum dipakai, media pembelajaran yang dibuat dilakukan review oleh ahli materi, ahli media dan ahli pendidikan karakter juga uji coba. Uji coba ini diikuti oleh 20 pebelajar. Penilaian pebelajar mengenai aspek pembelajaran menunjukkan bahwa media memiliki kualitas yang baik, termasuk kategori "Baik". Penilaian pada aspek ini mencakup 11 indikator yang tercermin dalam 11 item pada kuesioner.

Kemudian dilakukan operational field testing. Tujuan operational field testing yaitu untuk menentukan apakah produk yang dihasilkan sudah layak digunakan di sekolah tanpa kehadiran 


\section{Samsul Bakri}

pengembang. Supaya produk tersebut layak dalam penggunaan operasionalnya, pemaketan produk tersebut harus lengkap dan sudah diteskan dalam setiap aturan sebelumnya. Operational field testing sudah diteskan pada kelas umum dan situasinya sama seperti pada pengunaan operasional pada umumnya. Tanggapan dan saran pebelajar dalam tahap ini akan digunakan untuk merevisi produk untuk menjadi produk akhir sebelum disebarluaskan ke pengguna.

Dengan responden sebanyak 20 pebelajar yang memberikan tanggapan tentang kualitas media pembelajaran matematika dari aspek pembelajaran, materi, pendidikan karakter dan media, diperoleh hasil bahwa skor rata-rata keseluruhan (aspek pembelajaran, aspek materi, pendidikan karakter dan aspek media) dengan nilai "B", yang berarti termasuk dalam kategori "Baik"

Secara umum para pebelajar menyatakan bahwa media pembelajaran ini menumbuhkan motivasi dan memberikan manfaat yang cukup berarti dalam proses pembelajaran mata pelajaran matematika. Berdasarkan hasil operational field testing di atas, dapat dijelaskan sebagai berikut:

1) Semua pebelajar yang menjadi responden dalam uji coba lapangan menyatakan bahwa mata pelajaran matematika yang disajikan dalam produk media mudah dipelajari. (100\%)

2) Sebagian besar pebelajar yang menjadi responden dalam uji coba lapangan menyatakan bahwa konsep yang disajikan dalam produk media mudah dipelajari (85\%).

3) Sebagian besar pebelajar yang menjadi responden dalam uji coba lapangan menyatakan bahwa mata pelajaran matematika yang disajikan dalam produk media membuat para pebelajar merasa tertantang untuk belajar dengan lebih baik karena materi relatif mudah dipelajari dan mereka dapat terlibat secara aktif dalam proses pembelajaran karena telah disediakan lembar kerja yang dapat diisi oleh pebelajar. (90\%)

4) Semua pebelajar yang menjadi responden dalam uji coba lapangan menyatakan bahwa mereka ingin belajar banyak melalui media yang disediakan tersebut. (100\%)

5) Sebagian besar pebelajar yang menjadi responden dalam uji coba lapangan menyatakan bahwa dengan menggunakan media tersebut dapat digunakan sebagai cara penanaman nilai-nilai karakter bangsa. $(85 \%)$

6) Semua pebelajar yang menjadi responden dalam uji coba lapangan menyatakan bahwa media pembelajaran ini membantu mereka dalam mempelajari mata pelajaran matematika. (100\%)

7) Semua pebelajar yang menjadi responden dalam uji coba lapangan menyatakan bahwa mereka dapat mengukur pemahamannya dengan mengerjakan soal evaluasi yang disediakan karena setelah semua soal dikerjakan mereka dapat secara langsung melihat hasilnya. (100\%)

8) Sebagian besar pebelajar yang menjadi responden dalam uji coba lapangan menyatakan bahwa mereka dapat lebih cepat dalam mempelajari matematika dengan melalui media. (85\%)

9) Semua pebelajar yang menjadi responden dalam uji coba lapangan menyatakan bahwa mereka merasa senang belajar melalui media. (100\%)

10) Sebagian besar pebelajar yang menjadi responden dalam uji coba lapangan menyatakan bahwa mereka ingin belajar dengan media yang menarik pada mata pelajaran yang lain. (90\%)

11) Hanya (25\%) pebelajar yang menjadi responden dalam uji coba lapangan menyatakan bahwa mereka mengalami kebingungan dan tidak percaya diri jika tidak didampingi pada saat belajar dengan produk media. Ini berarti $75 \%$ pebelajar merasa mampu untuk belajar secara mandiri dengan produk media. 
12) Sebagian besar pebelajar yang menjadi responden dalam uji coba lapangan menyatakan bahwa lembar kerja yang disediakan membuat proses belajar mereka lebih aktif dan mudah. (85\%)

13) Semua pebelajar yang menjadi responden dalam uji coba lapangan menyatakan bahwa penyajian materi dengan berbagai media, seperti teks, gambar, tabel, suara, animasi, dan video, menarik. $(100 \%)$

14) Hanya (15\%) pebelajar yang menjadi responden dalam uji coba lapangan menyatakan bahwa petunjuk yang ada membuat mereka kebingungan. Sisanya (85\%) merasa mudah ketika menggunakan produk media dalam belajar sehingga proses belajar dapat berjalan dengan lancar.

15) Sebagian besar pebelajar yang menjadi responden dalam uji coba lapangan menyatakan bahwa mereka mempelajari materi secara runtut. (90\%)

16) Secara umum dapat disimpulkan bahwa pebelajar dapat memperoleh manfaat dengan belajar menggunakan media berbasis pendidikan karakter. Pebelajar juga menjadi lebih termotivasi dalam mempelajari maeri yang disajikan. Jadi media ini memiliki sumbangan yang positif terhadap proses pembelajaran.

Setelah mengadakan operational field testing, seperti sudah dijelaskan di atas bahwa untuk menentukan apakah penggunaan produk hasil pengembangan memiliki dampak yang positif terhadap hasil belajar yang diharapkan. Untuk mengetahui hal tersebut, pebelajar diberikan pre-test dan posttest untuk melihat apakah ada perkembangan yang signifikan pada hasil belajar pebelajar sebelum dan sesudah menggunakan produk tersebut. Pengolahan skor pre-test dan post-test dilakukan dengan bantuan program excel dan SPSS versi 16, sehingga dapat dikerjakan lebih cepat. Dengan melihat nilai pebelajar pada post-test, dapat diperoleh jumlah persentase pebelajar yang mencapai ketuntasan belajar dengan nilai minimal "70".

Dari data yang ada, dapat dijelaskan bahwa jumlah pebelajar yang mencapai ketuntasan belajar (nilai minimal 70) setelah pebelajar menggunakan media pembelajaran berbasis pendidikan karakter, sebanyak 17 pebelajar dari 20 pebelajar yang mengikuti tes tersebut, sehingga sebesar 72,25\% pebelajar yang dinyatakan mencapai ketuntasan belajar pada materi tertentu pada mata pelajaran matematika dan termasuk dalam kategori "Baik".

Dari data yang didapat, dapat disimpulkan bahwa dampak penggunaan media pembelajaran mata pelajaran matematika berbasis pendidikan karakter terhadap peningkatan hasil belajar pebelajar dalam mata pelajaran matematika masuk kategori "baik" dengan melihat jumlah persentase pebelajar yang mencapai ketuntasan belajar sebesar 72,25\%. Di samping itu, media pembelajaran tersebut juga mampu meningkatkan kesadaran pebelajar akan nilai-nilai karakter bangsa dalam kehidupan seharihari.

Setelah melewati beberapa tahapan uji coba, baik uji kelayakan terbatas dari ahli materi, ahli pendidikan karakter dan ahli media, maupun uji lapangan yang meliputi preliminary field testing, main field testing, dan operational field testing, produk media berbasis pendidikan karakter hasil pengembangan tersebut sudah layak menjadi produk akhir yang dapat disebarluaskan dan diimplementasikan kepada para pengguna. Kelayakan tersebut dilihat dari rata-rata penilaian hampir semua tahapan, memberi nilai "B" dengan kategori "Baik". Hal ini sesuai dengan harapan peneliti pada bab 3 dalam tesis ini, bahwa kelayakan yang ditetapkan oleh peneliti, minimal mendapat nilai "C", dengan kategori "Cukup Baik". 
Selain produk media berbasis pendidikan karakter hasil pengembangan tersebut sudah layak digunakan, produk yang dikemas dalam bentuk $C D$ interaktif tersebut juga mempunyai beberapa keunggulan lain dan beberapa kelemahan. Keunggulan yang pertama yaitu bahwa pembuatan $C D$ media interaktif ini, dengan menggunakan program Macromedia Flash 8, terbukti jauh lebih praktis dan lebih banyak memiliki keunggulan lain seperti tampilan lebih cantik, mudah dioperasikan dan sebagainya sehingga pebelajar tidak perlu harus menguasai program ini terlebih dahulu. Keunggulan yang kedua, yaitu dalam menjalankan $C D$ media interaktif pengembangan ini, $C D$ akan berjalan secara otomatis setelah dimasukkan dalam $C D$ ROM di komputer, karena $C D$ media interaktif hasil pengembangan ini sudah di-publish dalam bentuk file "exe" dan menggunakan sistem "autorun".

Keunggulan lain dari media berbasis pendidikan karakter hasil pengembangan ini juga mempunyai manfaat yang nyata, yaitu jumlah persentase pebelajar yang mencapai ketuntasan belajar setelah menggunakan media berbasis pendidikan karakter hasil pengembangan, sebanyak $72,25 \%$.

Selain mempunyai beberapa keunggulan, media pembelajaran berbasis pendidikan karakter ini juga mempunyai beberapa kelemahan, yaitu : (1) program Macromedia Flash 8 yang digunakan untuk membuat $C D$ interaktif ini membutuhkan banyak files pendukung, sehingga dalam pencarian memerlukan waktu yang cukup lama; (2) Diperlukan ketelitian dalam membuat $C D$ interaktif ini karena program Macromedia Flash 8 sangat rawan error apabila pengembang kurang teliti dalam membuat CD interaktif; (3) pemilihan jenis musik tidak dapat memenuhi semua keinginan pebelajar, karena pebelajar biasanya mempunyai gaya belajar dan kesukaan jenis musik yang berbeda-beda

Setelah menjadi produk akhir berbentuk $C D$ yang sudah direvisi berdasarkan semua tahapan uji coba dan layak digunakan, produk tersebut dapat disebarluaskan dan diimplementasikan ke pengguna. Meskipun $C D$ tersebut ditujukan untuk pebelajar, tapi tidak tertutup kemungkinan bagi guru ataupun masyarakat umum yang tertarik pada mata pelajaran matematika.

\section{SIMPULAN DAN SARAN}

Berdasarkan pembahasan dan uraian di atas, dapat ditarik kesimpulan sebagai berikut:

Pengembangan media berbasis pendidikan karakter ini menggunakan kaidah-kaidah pengembangan produk dari Borg \& Gall, yang meliputi: pendahuluan, pengembangan, uji lapangan dan diseminasi. Dengan menggunakan langkah-langkah penelitian dan pengembangan, model pengembangan program pembelajaran, dan langkah-langkah pengembangan media, dapat dihasilkan media pembelajaran berbasis pendidikan karakter untuk mata pelajaran matematika yang efektif. Berdasarkan hasil penelitian didapatkan hasil yakni: pada preliminary field testing yang diujicobakan terhadap 3 orang pebelajar termasuk dalam kategori "Baik" dengan skor rata-rata 3,93. Yang terdiri dari aspek pembelajaran 4,03 dengan kategori "Baik", aspek materi 3,93 dengan kategori "Baik", aspek pendidikan karakter 4, 07 dengan kategori "Baik", dan aspek media dengan 3,86 dengan kategori "Baik". Pada main field testing yang diujicobakan terhadap 10 orang pebelajar termasuk dalam kategori "Baik" dengan skor rata-rata 4,06. Yang terdiri dari aspek pembelajaran 4,08 dengan kategori "Baik", aspek materi 4,03 dengan kategori "Baik", dan aspek media dengan 4,06 dengan kategori "Baik". Sedangkan pada Operational Field Testing yang diujicobakan terhadap 20 orang pebelajar termasuk dalam kategori "Baik" hal ini dapat dilihat dari jumlah mahasiswa yang tuntas sebanyak 17 orang dari 20 pebelajar yang diujicoba. Dan berdasarkan jumlah persentase pebelajar yang mencapai ketuntasan belajar dengan nilai minimal "70", setelah menggunakan media 
pembelajaran berbasis pendidikan karakter ini, diperoleh sebanyak $72,25 \%$ dan termasuk dalam kategori "Baik".

Kualitas media pembelajaran berbasis pendidikan karakter hasil pengembangan ini, dari aspek pembelajaran memperoleh skor 4,11 termasuk kategori "Baik". Dari aspek materi memperoleh skor 4,02 juga termasuk dalam kategori "Baik". Dari aspek pendidikan karakter memperoleh skor 4,07 yang termasuk kategori baik. Dan dari aspek media memperoleh skor 4,02, ini pun termasuk dalam kategori "Baik". Secara keseluruhan kualitas media ini memperoleh kategori "Baik".

Produk media pembelajaran berbasis pendidikan karakter hasil pengembangan ini efektif digunakan. Hal ini terlihat dari hasil uji $t$ rerata skor pre-test dan post-test yang menunjukkan bahwa nilai probabilitasnya sebesar 0,000 , lebih kecil dari 0,05 , sehingga dapat disimpulkan bahwa rerata skor pre-test dan post-test berbeda secara signifikan.

\section{DAFTAR RUJUKAN}

Arsyad, Azhar. 2006. Media pembelajaran. Jakarta: PT. Raja Grafindo Persada.

Berkowitz, Marvin W., Melinda C Bier. 2005. What Works In Character Education: A Research-Driven Guide for Educators. Washington DC: Character Education Partnership.

Borg, W.R., \& Gall, M.D. 1983. Educational research: An introduction (4th ed.). New York: Longman.

Kusoema, Doni. 2010. Pendidikan Karakter: Strategi Mendidik Anak di Zaman Global. Jakarta: Grasindo.

Lickona, Thomas. "The Return of Character Education"Educational Leadership, Vol. 51 Number 3, 6-11, Nov 1993.

Lickona, Thomas. 1991. Educating for Character. New York: Bantam Books.

Lickona, Thomas. 2004. Character Matters. New York: Somon \& Schuster.

Lickona, Thomas. 2012. Mendidik untuk Membentuk Karakter. Jakarta: Bumi Aksara.

Megawangi, Ratna. 2004. Pendidikan Karakter; Solusi yang Tepat untuk Membangun Bangsa, Bogor: Indonesia Heritage Foundation.

Miarso, Yusuf Hadi, 2004. Menyemai benih teknologi pendidikan. Jakarta: Fajar Interpratama Offset Kerja sama dengan Pustekkom Diknas.

Muslich, Masnur. Pendidikan Karakter: Menjawab Tantangan Krisis Multidimensional. Jakarta: Bumi Aksara.

Samani, Muchlas. Hariyanto. 2012. Konsep dan Model Pendidikan Karakter. Bandung: PT Remaja Rosdakarya.

Tim Pengembang Pendidikan Karakter. 2011. Bahan Ajar Pendidikan Karakter. Jakarta: Kemendikbud.Muzaki, A. (2014). Pengembangan Media Pembelajaran Matematika Interaktif Berbasis Game Monopoli Dengan Macro Media Flash Pada Pokok Bahasan Teorema Pythagoras Untuk Sma Kelas X. Jurnal Penelitian, Pendidikan, dan Pembelajaran, 67-74.

Stylianou, D. (2015). Undergraduate Students' Understanding of Proof: Relationships Between Proof Conceptions, Beliefs, and Classroom Experiences with Learning Proof. Switzerland: Springer International Publishing. 
Suartama, I. (2010). Pengembangan Mutimedia untuk Meningkatkan Kualitas Pembelajaran pada Mata Kuliah Media Pembelajaran. Jurnal Pendidikan dan Pengajaran, Jilid 43, Nomor 3, Oktober 2010, hlm.253-262.

Susanah. (2012). Geometri. Surabaya: Unesa University Press.

Suyanto, M. (2005). Multimedia: Alat untuk Meningkatkan Keunggulan Bersaing. Yogyakarta: Andi Publisher.

Trianto. (2013). Model Pembelajaran Terpadu. Jakarta: Bumi Aksara.

Weber, K. (2015). Effective Proof Reading Strategies for Comprehending. Switzerland: Springer International Publishing. 